This item was submitted to Loughborough's Research Repository by the author.

Items in Figshare are protected by copyright, with all rights reserved, unless otherwise indicated.

\title{
European cities in advanced producer services and real estate capital flows: a dynamic perspective
}

\section{PLEASE CITE THE PUBLISHED VERSION}

http://dx.doi.org/10.4337/9781782544654.00014

PUBLISHER

(C) Edward Elgar

VERSION

AM (Accepted Manuscript)

\section{PUBLISHER STATEMENT}

For private use only. Any download is for personal use only.

LICENCE

All Rights Reserved

\section{REPOSITORY RECORD}

Hoyler, Michael, Colin Lizieri, Kathryn Pain, Peter J. Taylor, Sandra Vinciguerra, Ben Derudder, and Daan Pelckmans. 2019. "European Cities in Advanced Producer Services and Real Estate Capital Flows: A Dynamic Perspective”. figshare. https://hdl.handle.net/2134/15293. 


\title{
European cities in advanced producer services and real estate capital flows: a dynamic perspective
}

\author{
Michael Hoyler \\ Department of Geography, School of Social, Political and Geographical Sciences, \\ Loughborough University \\ Colin Lizieri \\ Department of Land Economy, University of Cambridge \\ Kathy Pain \\ School of Real Estate and Planning, Henley Business School, University of Reading \\ Peter Taylor \\ Faculty of Engineering and Environment, Northumbria University \\ Sandra Vinciguerra \\ School of Real Estate and Planning, Henley Business School, University of Reading \\ Ben Derudder \\ Department of Geography, Ghent University \\ Daan Pelckmans \\ Department of Geography, Ghent University
}

\section{Introduction}

As emphasized in Chapter 1, the implications of economic globalization for Europe have been a major concern of the European Union (EU) and its constituent member states for over a decade. As discussed in Chapter 5 the advanced global economy now functions as complex horizontal networks of firms, made possible by developments in information and communications technology (ICT) since the 1970s. A consequent paradigm shift in the spatial organization of the global economy has led the geography of territorial structures such as the EU, its nation states and their borders, to be overlaid by more fluid relational spaces generated by business networks in which cities have a critical functional role. Amongst these networks, city-located APS (advanced producer services), finance and linked business services, have come to have rising prominence in the world economy from the latter years of the twentieth century onwards, as recognized in the EU Lisbon Strategy to boost Europe's economic competitiveness in a global context (EC, 2000). Hence, in this chapter, we focus attention on the role and position of European cities in the evolving APS network economy. 
Advanced producer services were first identified by Friedmann (1986) as having a key role in the process of capitalist 'world city' formation and by Sassen (1991, 1994) as having complementary geographic dispersion and concentration dynamics which result in a new economic role for 'global' cities. But it was Castells' theorization of a 'space of flows' constituted by a 'multi-edged network' (1996, pp. 75-6) which drew attention to the way in which APS business organization now interconnects cities worldwide in an economy that is 'informational, global, and networked' (1996, p. 77; Beaverstock et al., 2000). As the operational 'nodes' for information and financial flows in worldwide office networks, cities have become interlinked across territorial borders, characterized by specialized 'functional transnationality'. Indeed, globally linked cities are the specific geographical locations in the world for global APS network centralities (Sassen, 2002). So although Castells recognized that a space of flows was 'transcending' the politically constructed, territorial scales of the 'space of places' (1996) this has not diminished the importance of contemporary cities as geographically situated, governed places (Hoyler and Pain, 2002).

In spite of predictions that developments in ICT heralded the 'end of geography' and urban business clustering, in-depth interviews held with senior APS actors working in Northwestern Europe have found that the most important international business relationships, skills, knowledge flows, innovations and transactions still occur in offices in major global cities and this clustering dynamic is expected to continue (Taylor et al., 2003; Hall and Pain, 2006; Hoyler et al., 2008). Hence the digitization and financialization of 'invisible' trade has not lessened APS network centralities and the spatial concentration of specialized high complexity, high-value-added functions. Moreover, global firms say that increasingly competitive global APS markets require their presence in the deep infrastructure of the world's major global cities such as London and New York.

It follows from these parallel operational requirements for co-location and functional concentration that the global space of APS inter-city flows is intrinsically dependent on the availability of appropriate physical city infrastructures such as state-of-the-art office real estate developments, ICT and multi-modal transportation, including international airport hubs (Pain, 2011). In other words, the material form of cities and their supply of commercial office real estate are interdependent with their functional role in these important sectors of the global economy. Furthermore, office real estate has been financialized and 'repackaged' as an international, tradeable financial asset (Coakley, 1994; Lizieri, 2009) leading to functional integration between global finance and real estate in global and globalizing cities. 
Due to financial deregulation and the creation of new international investment funds since the latter part of the twentieth century, APS foreign direct investments (FDIs), occupation and the ownership of city office space have all risen sharply, as have inter-city capital flows (Lizieri and Kutsch, 2006; Lizieri et al., 2011). The result is an 'interlocking' between APS location drivers, office occupation and financial investments; hence, centralities in global financial and linked business networks are replicated and reinforced by international real estate investment flows. This begs the question whether the geographies of real estate capital flows can be regarded as a proxy for those in global financial networks and, if so, whether the world's most prominent global cities are especially vulnerable to volatility in the global financial system as a consequence (Lizieri, 2009).

As noted by Lizieri (2009) the physical infrastructure of cities partially 'locks down' and 'fixes' cross-border capital flows in international office markets, hence, in the context of neoliberalization, urban administrators have come to regard APS inward investment as a vital source of finance 'to mobilize city space as an arena both for market-oriented economic growth and for elite consumption practices' (Brenner and Theodore, 2002, p. 21; Peck and Tickell, 2002; Swyngedouw et al., 2002; Knox and Pain, 2010). Understanding the intertwined relations between finance and real estate flows is therefore of major relevance for Europe 2020 priorities for economic growth and for the issue of where development occurs, which is the primary concern of the territorial cohesion objective (EC, 2000; CEC, 2010, 2011, 2012).

This chapter addresses this concern through an empirical study of APS office networks and international office real investment flows. First we describe the bespoke data and innovative analytical methodologies employed in our research. Second we examine the changes in the APS global space of flows, and the position of Europe within this, from the year 2000 (the time of the launch of the EU Lisbon Strategy) to 2010. Third, we consider the impact of the global financial crisis on international office real estate investment flows. We compare their network centralities with those for financial services networks in order to establish whether real estate capital flows can be considered a proxy for global city financial concentration and we examine whether Europe's international financial centres are vulnerable to real estate office market falls in periods of financial instability by examining flow data for the years immediately before and after the crisis. Finally, we draw attention to the main implications of our results for Europe 2020 and territorial cohesion policies. 


\section{Data, analyses and network visualizations}

Unique primary data collected by the Globalization and World Cities (GaWC) Research Network $^{1}$ in four census periods between 2000 and $2010^{2}$ were used in our APS analyses. ${ }^{3}$ Taylor's interlocking network model ${ }^{4}$ was employed to calculate the global 'connectivity' that is conferred on cities worldwide by APS firms and which generates a functionally interlinked 'world city network' (WCN) (Taylor, 2001, 2004; Taylor et al., 2011). The size of APS offices and their functions in the global network of an individual firm gives rise to intra-firm linkages between the cities where they are located and hence to inter-city functional linkages. Calculating the total connectivity generated by all the global firms present in a given city thus shows the position of that city in the APS world city network. By applying the interlocking network model in our research we have thus been able to plot the connectivities, positions and functional interlinkages of European cities in the world city network between 2000 and 2010. We have adopted a time-series approach to analysis in order to shed light on changing dynamics during this period and we have also undertaken specific sectoral analyses in order to inform understanding of the role of financial and other sectors in shaping European spatial relations in the network economy.

While comparisons between relative connectivity values suggest a vertical hierarchical ranking of cities, it is important to understand that what is being measured in GaWC APS analysis is how well a city is connected to all others in the worldwide network of global cities, hence the inter-city relations and relative network positions of cities represent cross-border functional complementarities between them and not competitive relations. However, as we will explain in due course, world city network connectivity and inter-city office real estate capital flows are highly integrated; hence there are important territorial outcomes from a city's network positionality.

In order to be able to make the time series comparisons for the GaWC census periods, it was necessary to standardize the four datasets which contained different numbers of firms, cities and APS sectors. ${ }^{5}$ Standardization was undertaken at the level of city pairs (dyads) ${ }^{6}$

\footnotetext{
${ }^{1}$ See www.lboro.ac.uk/gawc.

${ }^{2}$ The 2010 data have been added to our analyses since the completion of the original ESPON funded research and so are not included in the official final report.

${ }^{3}$ The sectors studied were banking and finance, together with specialized legal, accountancy, advertising and management services, which have complementary business relations in global markets.

${ }^{4}$ For full technical details about the model and measurement method, see Taylor $(2001,2004,2012)$. See also Borgatti et al. (2002), for an explanation of the software used in the network analysis.

${ }^{5}$ The data standardization method is explained in detail in Tiger Final Report Working Paper 3 (Pain et al., 2012). It differs from standardization procedures employed by Taylor and Aranya (2008),
} 
for a total of five sectors: accountancy, law, advertising, management consulting and financial services for the following numbers of firms and cities worldwide:

1. Year 2000: 100 APS firms present in 315 cities.

2. Year 2004: 92 APS firms present in 315 cities.

3. Year 2008: 175 APS firms present in 525 cities.

4. Year 2010: 175 APS firms present in 526 cities.

A subset of 285 cities present in all four datasets was then used for further analysis.

Real estate investment flows not only between, but also within, cities worldwide were analysed using Real Capital Analytics (RCA) data on the top 1000 commercial property transactions in each year from 2007 to 2010. Information on recorded deals checked and triangulated by RCA was used to compile a dataset suited to our analyses. Information on office property location, price, and buyer identity and location, was used to trace all recorded deals geographically, resulting in a dataset similar to an origin-destination matrix. We identified both the location of office property sold and the location of the purchaser of that property, defined as the headquarters of the beneficial owner, for every commercial deal in the real estate database in order to elicit the capital flows generated by international investors. In some instances the purchaser location was unclear. In the case of 'off-shored' or tax-haven purchaser headquarters we researched the location of the effective operational headquarters. Where financial firms have acted as asset managers for a wide range of investors whose identity is unknown, we have used the location of the principal office of the fund manager. While this may differ from the head office of the parent company, for example, when a Swiss bank manages its real estate funds in London, this latter location reflects both the origin of the capital going into the funds and also the location of the asset managers generating the associated capital flows. In deals involving multiple investors in joint ventures, in the absence of clear capital shares, we divided the acquisition price into equal parts. In this way we produced a final dataset comprising 297 cities worldwide showing global networks of major financial investments in the commercial office real estate market for the 2007-10 period. Both aggregated and annual data ${ }^{7}$ are referred to in this chapter. The aggregated data provide a robust overview of the deals taking place between 2007 and

Derudder et al. (2010) and Hanssens et al. (2011), which explains minor differences in ranks of cities compared to those previously reported.

${ }^{6}$ The term 'dyad', as referred to here, indicates the relations between a pair of cities that are generated by the APS networks which are interlinking them in the world city network (Taylor et al., 2013).

${ }^{7}$ Annual fluctuations are short-term however these results are controlled for by data aggregation over the longer-term 2007-10 time period. 
$2010,{ }^{8}$ whereas annual data allow us to examine changing capital flows before and after the global financial crisis.

In order to examine the respective network structures for financial services and real estate investments, Pearson and Spearman Correlation and Quadratic Assignment Procedure (QAP) tests were applied to comparable data sets for a subset of 141 cities (Krackhardt, 1988). ${ }^{9}$ Because the central purpose of this chapter is to examine the position of European cities in these networks, mappa mundi analyses (Vinciguerra et al., 2010) ${ }^{10}$ were used to visualize these network structures when geographical distance is not considered and 'dyad' interlinkages between specific pairs of global cities. In some cases we also group cities territorially either at the level of the nation state or the EU to show how the space of flows maps onto the space of places. ${ }^{11}$ In this way we depict the functional relationships between European and other global cities in an evolving business and financial network space.

\section{Europe's position in world city network emergence - APS global rebalancing}

\section{A global overview}

The results from APS time series data analyses show that London, New York, Hong Kong and Paris have maintained stable leading positions in the world city network from 2000 to 2010. However, 171 out of the 285 cities included in our database increased their global network connectivity during the period up to the global financial crisis. This general rise in city connectivity was associated with a significant change in the relative positions of cities in the world city network. The major change noted has been a dramatic increase in the global connectivity of cities in the Pacific Asia region, especially Shanghai, Seoul, Sydney and Beijing. Shanghai and Beijing raised their world city network positions dramatically from 28th and 30th respectively in the year 2000 to 8th and 10th in 2008. In contrast, North American connectivity mainly comes from New York, Chicago and Toronto. Other US cities have

\footnotetext{
${ }^{8}$ It must be noted that data accuracy is more challenging to achieve in less transparent investment markets.

${ }^{9}$ The Pearson and Spearman and Quadratic Assignment test procedures, network analyses and visualization methods used are explained in detail in Tiger Final Report Working Paper 9 (Lizieri et al., 2012).

${ }^{10} \mathrm{~A}$ spring embedding algorithm is used to generate these network analyses. See Borgatti et al. (2002) for further information about the technical details and methodology.

${ }^{11}$ Country-level data also have significance for understanding the territorial implications of global network changes because, in general, nation states retain a key role in regulating APS and financial activity within their borders and in determining a wide range of policies which can present barriers to, or levers for, inward and outward city investment flows.
} 
experienced a declining relative world city network position due to global West-East rebalancing combined in some cases with actual falls in connectivity which may have been associated with the recent financial crisis.

Nevertheless, there has been a general decline in city APS global connectivity between 2008 and 2010 in the aftermath of the financial crisis and the onset of world economic recession with some notable exceptions. London has retained its 2008 connectivity level but the real surprise has been that Dubai has experienced a huge recent connectivity increase, which has also changed its world city network position from 48th in 2008 to 10 th in $2010 .{ }^{12}$ Shanghai's world city network position continued to rise to 6th in 2010.

Inter-city dyad links both for general APS network connectivity and for financial network connectivity have remained strongest between London and New York during the whole 2000-10 period. However, links between many other city pairs have strengthened, many of which involve cities in Europe.

We have used a mappa mundi analysis to visualize the territorial implications of these relational changes (Vinciguerra et al., 2010). Considering the global financial services networks, we see that the UK appears to be in a peripheral world city network position in spite of the stable top global position of London in each census period, due to the relatively weak global connectivity of other UK cities (Figures 1 and 2). On the other hand the US has retained a relatively central network position due to the size of its national territory and its larger number of cities with APS offices than is the case in the UK. Country size can thus be relevant in a competitive territorial paradigm. We see that China is rapidly gaining world city network centrality principally due to the upsurge in connectivity of Shanghai and Beijing and the stable leading position of Hong Kong. The development of other globalizing Chinese cities can be expected to accelerate this centralizing dynamic (Derudder et al., 2013).

\footnotetext{
${ }^{12}$ Dubai's financial difficulties, centred on real estate development, which emerged in late 2009, might affect its future ranking.
} 


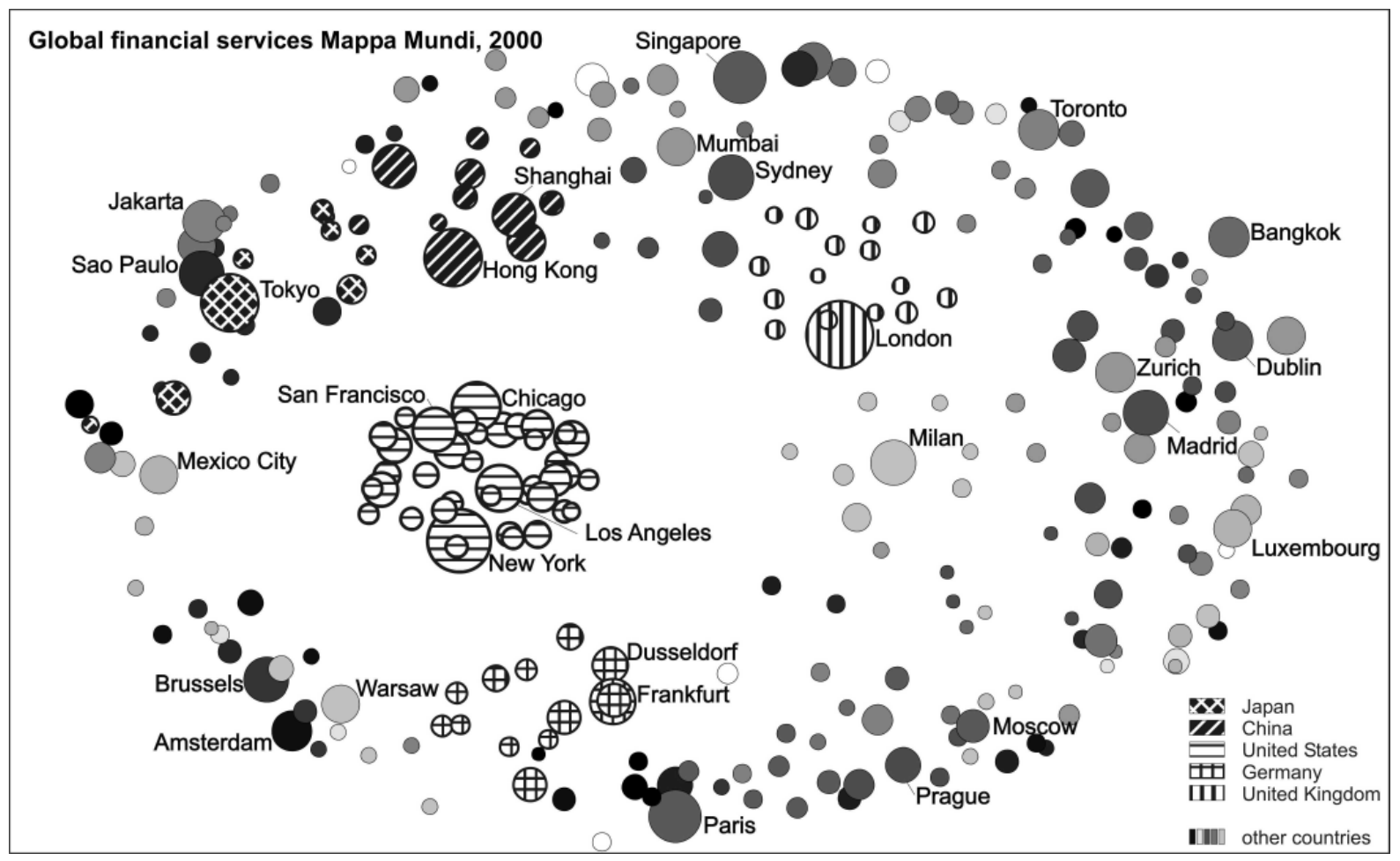

Figure 1 Global financial services mappa mundi, 2000

Source: Data - GaWC (http://www.lboro.ac.uk/gawc/).

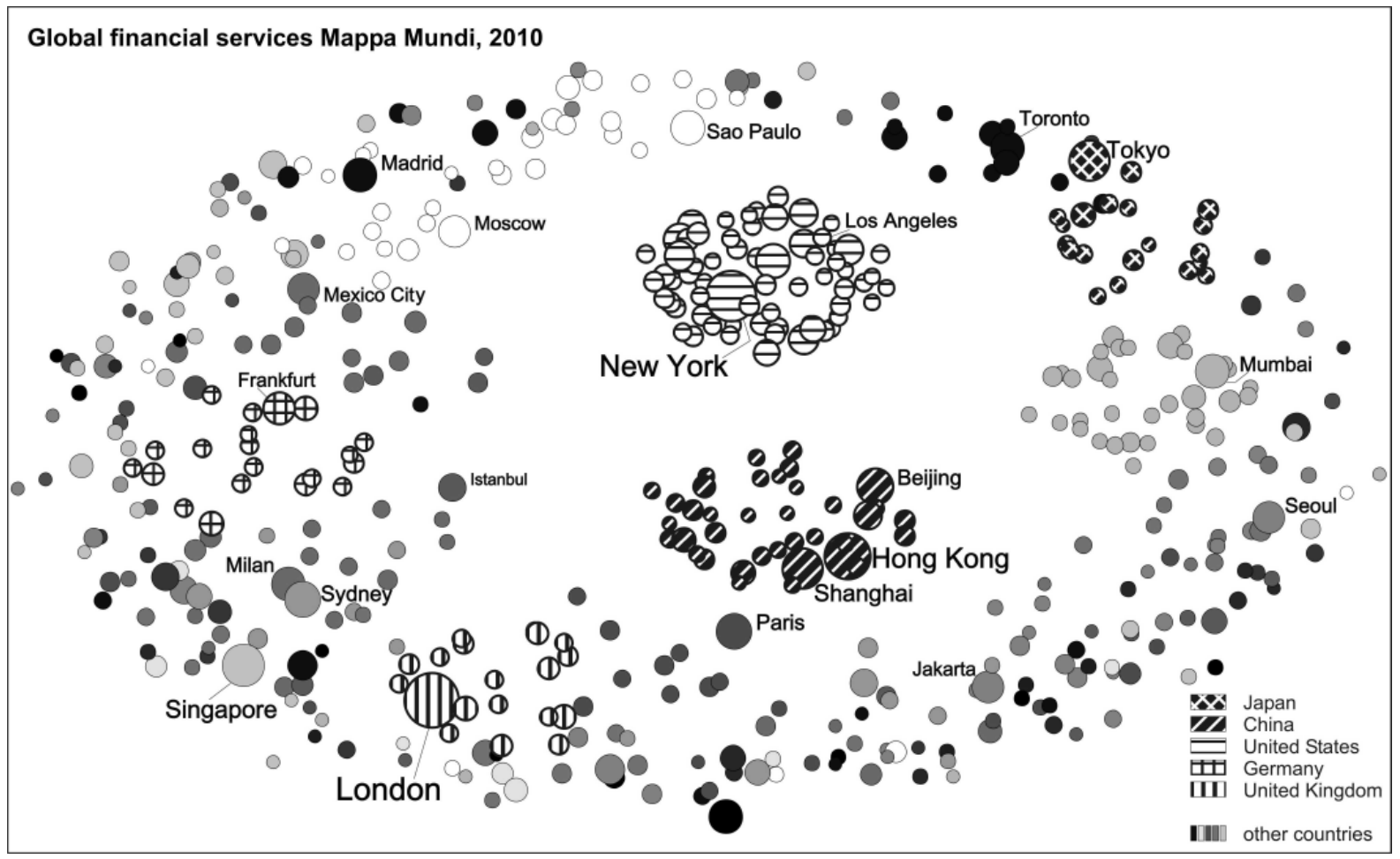

Figure 2 Global financial services mappa mundi, 2010

Source: Data - GaWC (http://www.lboro.ac.uk/gawc/). 
When we take the territorial scale of the EU geo-political constitution into account in the analysis, we see that 64 out of 95 European cities increased their world city network connectivity between 2000 and 2010 in spite of the recent global crisis and recession. Frankfurt, however, surprisingly suffered a decline in global connectivity during this period and its world city network position fell from 14th in 2000 to 19th in 2010. At the scale of the European sub-net of cities, London's leading position is followed up by Paris, Milan and Madrid, in each of the years 2000, 2008 and 2010. These cities were followed by Frankfurt, Amsterdam, Brussels, Dublin, Zurich, Munich, Vienna and Warsaw by 2010. Eastern European cities Warsaw, Prague and Budapest have strong network connections with London and Paris but although their global connectivity increased through the decade to 2008, this has generally declined again since the crisis except in the case of Warsaw. The pace of China's network centralization since the introduction of the 'Open Door' economic policy is impressive and it may be that Eastern Europe's changed political-economy position in globalization may also be gradually changing its global network connectivity, led by Warsaw.

European cities in general are comparatively well connected within the world city network in a global context and, taking a closer look at the spatial strategies of 160 global APS firms (of the 175 firms in the global data set) that chose to locate their offices in European cities in 2008, demonstrates the importance of their geo-functional business network positioning for the EU territorial space. For this analysis only cities with general network connectivity of 0.2 and above were considered, resulting in a database of 117 European cities and 160 firms. Principal components analysis ${ }^{13}$ reveals the inter-city relations generated by the European strategies of these firms for six factors in the year 2008, benchmarking the way firms were using European cities before the economic recession hit:

1. The "'Outer" European Capitals Strategy' - firms focusing principally on cities other than London and Paris, especially cities in Eastern and Southern Europe such as Warsaw, Budapest, Prague, Bucharest, Athens and Lisbon.

2. The "Primate" (London) Strategy' - firms focusing only on London for their European work.

\footnotetext{
${ }^{13} \mathrm{~A}$ standard Varimax rotation was applied and the output scores allowed analysis of city relational outcomes generated by 160 firms. For six factors, output scores could be interpreted as representing the strategies of the global firms using cities in the European territory (see Table 24, Pain et al., 2012).
} 
3. The 'Major Western Europe Cities Strategy' - firms focusing principally on Frankfurt, Madrid, Amsterdam, Zurich and Milan but not including London or Brussels.

4. The 'German Strategy' - firms focusing principally on Frankfurt, Munich, Dusseldorf, Hamburg and Berlin.

5. The 'British Strategy' - firms focusing on UK cities including medium-sized cities such as Bristol, Southampton and Cardiff.

6. The 'Dual Strategy' - firms focusing on a Paris-Brussels axis.

This analysis sheds light on the ways in which the strategies of global firms and the different features of cities in Europe interact, generating an interweaving European network of intercity functional relations. The 'outer' European capitals strategy demonstrates that city connectivity generated by global firms is leading to significant functional interrelationships between Europe's 'less primate' cities (Figure 3). Digging deeper into the database also shows the important influence of non-financial services firms in European cities - 79 per cent of firms are involved in the outer European cities strategy, mainly in accountancy and advertising. In contrast, in the European 'primate' city strategy, which focuses specifically on London, 51 per cent of firms are in financial services. There appears to be no general northsouth contrast shown by our results but there are notable strategic east-west patterns shown by the major Western Europe cities strategy, suggesting that fractured territorial relations between Eastern and Western Europe during the time of the 'Cold War' are still influencing the geographical pattern of European city development. 


\section{European strategies of global firms, 2008}
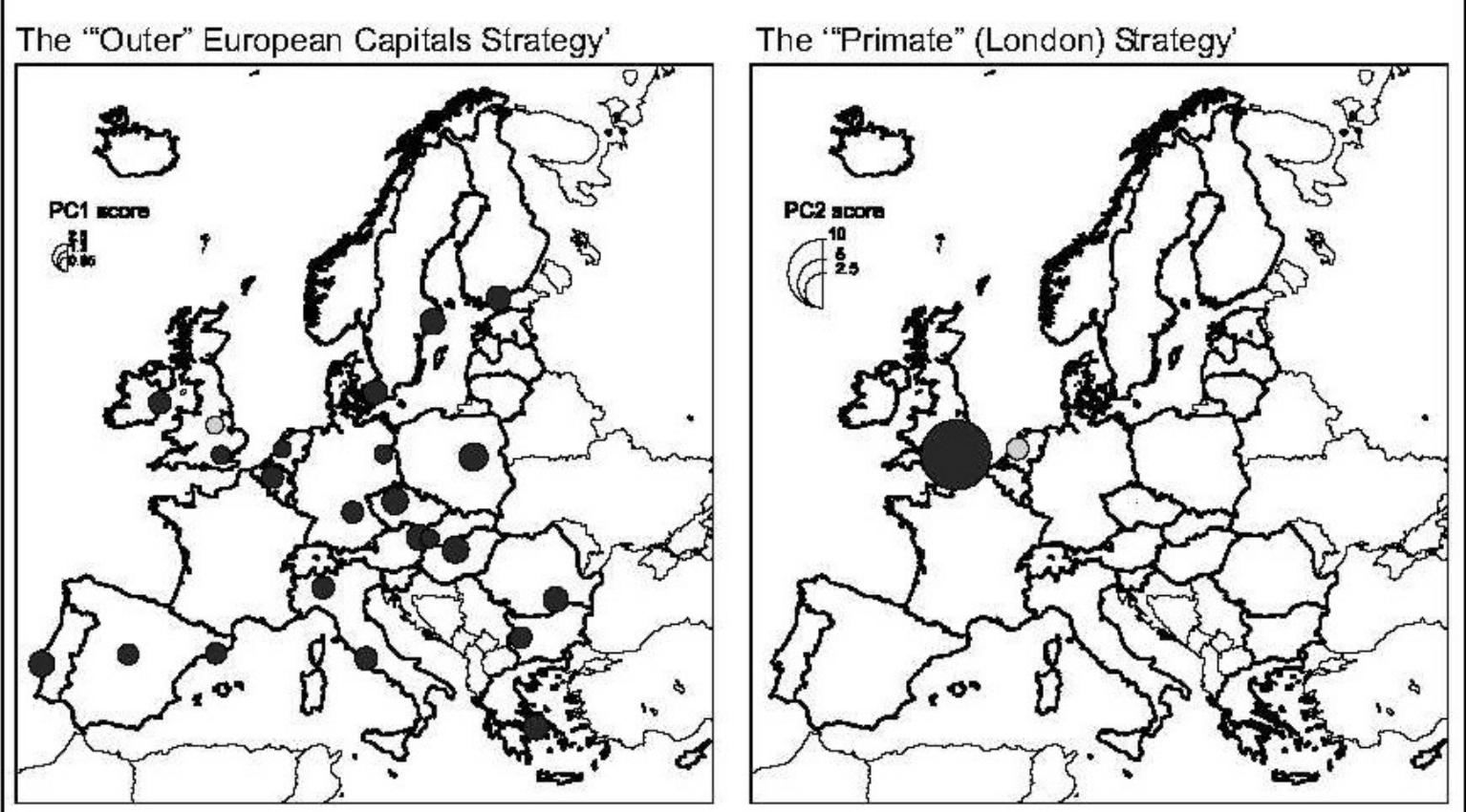

The 'Major Western Europe Cities Strategy'

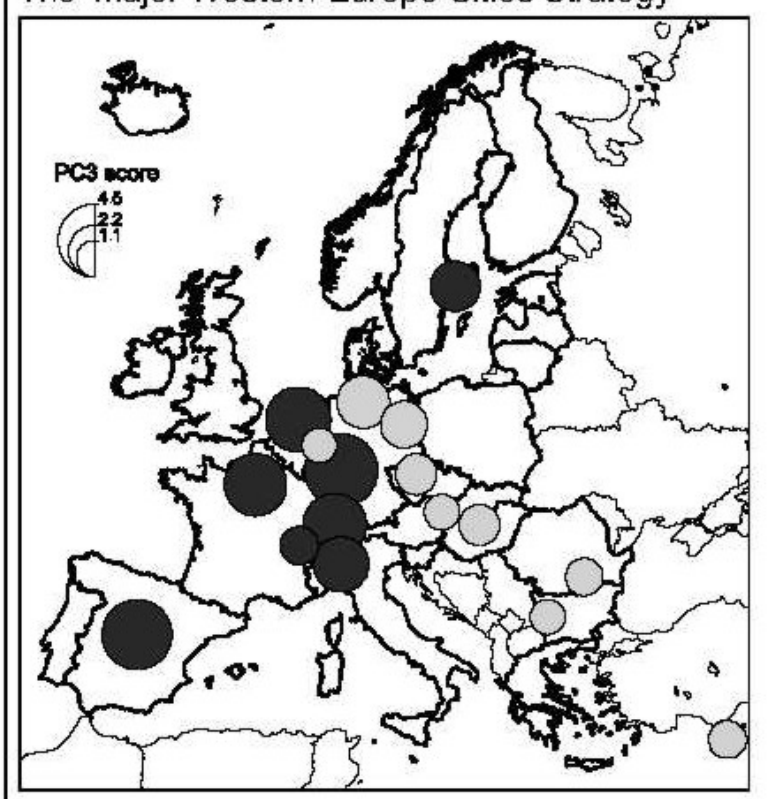

PC score $<-1$

PC acore > 1

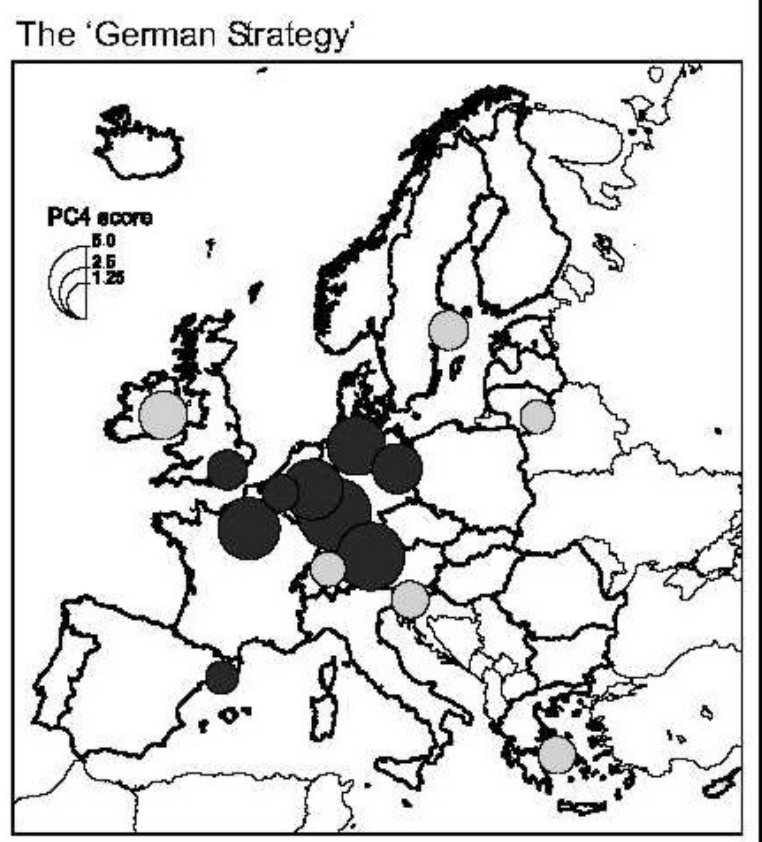

Eource : Uhweralty of Readhs, 2012 Orlah of diat : Ganc 2000

Figure 3 European strategies of global firms, 2008

Source: Data - GaWC (http://www.lboro.ac.uk/gawc/). 
The issue of which specific APS sectors are driving contemporary city connectivity changes and the city functional linkages generated by them is clearly important to inform EU and member state policies to support further city economic growth in a European and global context.

Not all of the 285 cities that we have studied worldwide are well connected to financial services networks. London and New York have retained their supreme world positions as global financial services nodes, followed by other mature world cities Hong Kong, Singapore, Tokyo and Paris, with Shanghai now joining this developed world grouping positioned in the world city network between Singapore and Tokyo. Interesting for Europe is the extremely close geographical proximity of Europe's two leading world financial centres, London and Paris, now supported by the high speed under-Channel rail link. Also of interest is the rise of EU neighbouring city, Moscow, since 2000. Moscow had the highest financial services connectivity increase between 2000 and 2008, raising its world city network position from 42nd in 2000 to 16 th in 2008. However, as has been the case with most Eastern European cities, this connectivity fell back in the wake of the crisis giving it a 2010 network position of 21 st in the dynamic world reordering of global financial centres.

Mappa mundi visualization illustrates the territorial implications of financial services changes for nation states, showing that in spite of the consistent network centrality of the US in global financial services networks, China (now with three major international financial centres, Hong Kong, Shanghai and Beijing), had achieved a similar central position in financial services networks by 2008 . This is reflected in the rank position of Shanghai, which has changed from 18th in 2000 to 5th in 2010, in spite of ${ }^{14}$ the crisis. Moreover, Beijing's rank position has risen from 24th in the year 2000 to 9th in 2010. These changes demonstrate that financial services are a key contributor to China's world city network centralization.

Albeit, London has consistently maintained its top world financial services ranking followed by New York across the census periods examined. Elsewhere in Europe, cities are less well connected by financial services than other APS sectors. Indeed, worldwide and before the crisis, just 82 cities increased their global financial services connectivity between the years 2000 and 2008, compared with 37 cities by 2010. Other APS sectors have been generating global APS connectivity increases in European cities, Luxembourg being an exception in Western Europe and Warsaw having outperformed Eastern European cities up until 2008.

${ }^{14}$ Or, possibly because of the crisis ... 
So we next consider which other sectors have been contributing to European global network connectivity in the relatively stable world economic context up until the crisis struck.

As might be expected, both London and Paris have strong global accountancy network connectivity, with London's network connectivity and position ahead of that of New York in all four census periods. But across Eastern Europe, Warsaw, Bucharest, Prague and Budapest followed by Sofia, Ljubljana and Krakow, have all been locations for increased accountancy connectivity (note the "'Outer" European Capitals Strategy') and this is significant for urban policy given that up until the crisis, as many as 173 cities in the world had increased their connectivity in global accountancy networks, including cities in the emerging Pacific Asia economic region such as Beijing, Shanghai and Seoul.

In contrast, apart from Warsaw, Eastern European cities have been less globally well connected by advertising firms in spite of their high concentration in both London and Paris. Possibly of interest here is that New York's position in advertising networks has been ahead of that of London in all four years surveyed. Altogether 176 cities worldwide increased their connectivity in this sector to 2008 and amongst these, cities in emerging markets experienced dramatic advertising connectivity increases. Moscow had the largest rise in advertising connectivity and network position (53rd position in 2000 rising to 7th in 2008) and Shanghai also leapt from 41st position in 2000 to 8th in 2008. But in considering city resilience during the aftermath of the crisis, it is significant that Moscow's advertising rank position fell to 19th in 2010 compared to that of Shanghai, which fell only to 10th position.

As in the case of accountancy, management consultancy firms have also been generating increasing global connectivity in Eastern Europe up to 2008, led this time by Budapest and Warsaw even though in this case, New York has consistently maintained a significantly higher connectivity level across the survey period than London. Again this is a significant finding for policy since 169 cities in the world increased their world city network connectivity in this sector during the same period, especially Hong Kong and Singapore as well as some Chinese cities that had no global connectivity in this sector in 2000. Many cities experienced increased management consultancy connectivity by 2008, linking them to North American cities, Chicago, Boston, Washington, Toronto and Dallas.

In contrast to other sectors, the level of connectivity of cities to law networks has been relatively stable, with just 62 cities worldwide gaining global connectivity and many cities losing connectivity between 2000 and 2008. However, important for Europe, Paris increased its global network position in this sector from 7th in 2000 to 3rd in 2008 (just after London 
which is consistently ahead of New York) but falling to 6th position in 2010, while Brussels gained, moving from 6th position in 2008 to 5th position in 2010, just ahead of Paris.

\section{The global financial crisis}

Real estate investment flows and network centralities

Aggregated office real estate investment data for the period 2007-10 reveal the cities which are acting as nodes and focal points for finance capital flows before and since the onset of the financial crisis. Capital flows into (in-flows), out of (out-flows) and within cities (selfinvestments) worldwide are first examined. ${ }^{15}$

The results show that Europe's top global city London dominates as a key node for real estate capital in-flows (in-flows \$33.64 billion; out-flows \$12.65) whereas, in contrast, New York has more dominant out-flows than in-flows (in-flows $\$ 14.74$ billion; out-flows $\$ 33.73$ billion). Between 2007 and 2010, New York's extensive out-flows have been invested in office property in 48 cities; however, only 22 cities have been investing in New York, whose top three international inter-city dyads were London, Paris and Frankfurt. In contrast to the position of New York, 34 cities have been investing in London whereas London has only invested in 27 other cities. Significantly, the top three dyads of London (the third global node for out-flows, but investing only half the money of New York) are all European cities Madrid, Paris and Brussels - with New York being its fourth dyad. Interestingly, the three top nodes for intra-city, self-investment flows are the three 'global cities' originally identified by Sassen (1991) - New York, Tokyo and London - demonstrating both the investment concentration within these mature financial centres and the importance of critical mass in city capital and real estate markets.

Looking at the worldwide rank order of city in-, out-, and self-investment flows, other interesting results are those for Hong Kong, which ranks just 43rd for in-flows and 16th for out-flows compared with a self-investment rank of 7 (only just behind Paris [4], Seoul [5] and Moscow [6]), suggesting that Hong Kong may be less active as a conduit for Asian investment flows than might be expected. Very many other cities worldwide - 236 in all are also nodes for in-flows and 122 cities are nodes for out-flows but, by comparison, only 66 cities are nodes where intra-city (self-) investment is occurring, which may be indicative of

\footnotetext{
${ }^{15}$ Links between nodes in the global network of real estate investment flows represent the aggregation of commercial deals generating investment in-flows and out-flows taking place between pairs of cities (dyads) and within cities (self-investments).
} 
their less established office property markets. In general, it is mature cities that are seen to dominate the higher in-flow, out-flow and self-investment rankings, and top ranked global cities - London, New York and Tokyo - have significantly higher overall flow levels, suggesting that they are the leading global spaces for both office real estate finance and APS centralities.

Within Europe, Paris demonstrates a similar distribution of investment flows between 2007 and 2010 to that of London, ranking 3rd as a node for in-flows, 27th for out-flows and 4th for self-investment. Looking at other European investment geographies, Munich has been the 4th city for out-flows within Germany with cross-border links to multiple other European cities, as well as extensive dyad relations across the world. Frankfurt has been Europe's 5th outward investor followed by Dublin (6th), Hamburg, (7th) and Madrid (8th). Frankfurt's key dyads are Paris, London, Prague, Warsaw and Shanghai, and then a European/global mix of cities including Bucharest and Wroclaw in Eastern Europe. In contrast, Brussels' main dyads are more Eurocentric - Amsterdam, Dublin, Frankfurt, London, Madrid, Munich, New York and Zurich. The results for Eastern European cities show that their attractiveness as global destinations for investment in-flows is much weaker than that of Western European cities, reflecting the present limited size of their prime, Class $A$, office space markets. The best performing East European cities for in-flows between 2007 and 2010 are Prague (rank 23) and Warsaw (rank 30). In-flows to Eastern Europe are coming through Prague (from Frankfurt, Munich, Trieste and Vienna); Warsaw (from Frankfurt, Hamburg, London, Stockholm and Wiesbaden); Bucharest (from Frankfurt, Paris and Vienna); and Budapest (from Hamburg, Munich and Vienna).

Mappa mundi visualization shows that European countries, the UK (ranked 1st), followed by France and Germany, have been ahead of the US and China, respectively, in their volume of in-flows for the whole 2007-8 period. Within Europe, the UK ( $\$ 36.17$ billion) has been especially important having had more than twice the in-flows of France ( $\$ 15.11$ billion) and significantly higher volumes of in-flows than Germany. At the same time, out-flows from the UK (ranked 3rd / \$12.01 billion) were significantly lower in volume than those of Germany (2nd / \$25.75 billion) and the US 1st / \$34.09 billion). Many cities have contributed to 200710 US outflow dominance over in-flows compared to the UK. Eastern European countries, the Czech Republic, Hungary, Poland and Romania have had no self-investment or out-flow scores but they have ranked higher for in-flows suggesting that their internal capital markets have not yet developed sufficiently for their investors to participate in major global real estate transactions. 
Focusing on the value of office real estate investment deals for city dyads, we see the amounts of finance capital passing between any two cities during the 2007-10 period. This allows us to identify which specific cities are the originators of outbound, and the recipients of inbound, investments in inter-city relations. In this case, we focus specific attention on the roles of mature financial centres in articulating the in- and out-flow investments at different geographical scales. The 2000-8 GaWC data for financial services network connectivity identify London, New York, Tokyo, Hong Kong, Singapore and Paris as the six major world financial centres with a consistent top ranking during the past decade. Next we consider the position of these cities in international real estate investment flows at the time of the financial crisis.

Financial services and aggregated real estate data reveal that cities with high global real estate investment in-flows also have high financial services network connectivity scores (Figure 4). There is thus a strong inference that interdependencies between global financial services networks and real estate office markets are constructing intersecting network centralities in global cities. As many as 141 cities in the world are interconnected through both global finance and real estate investment networks, albeit their connectivity rankings vary substantially. As might be expected, London (rank 1) and New York (rank 2) are the best-connected world cities for both financial services network connectivity and for real estate in-flows; however, as already discussed, London has nearly three times the real estate in-flows of New York which may reflect its supreme role as an international financial services centre. 


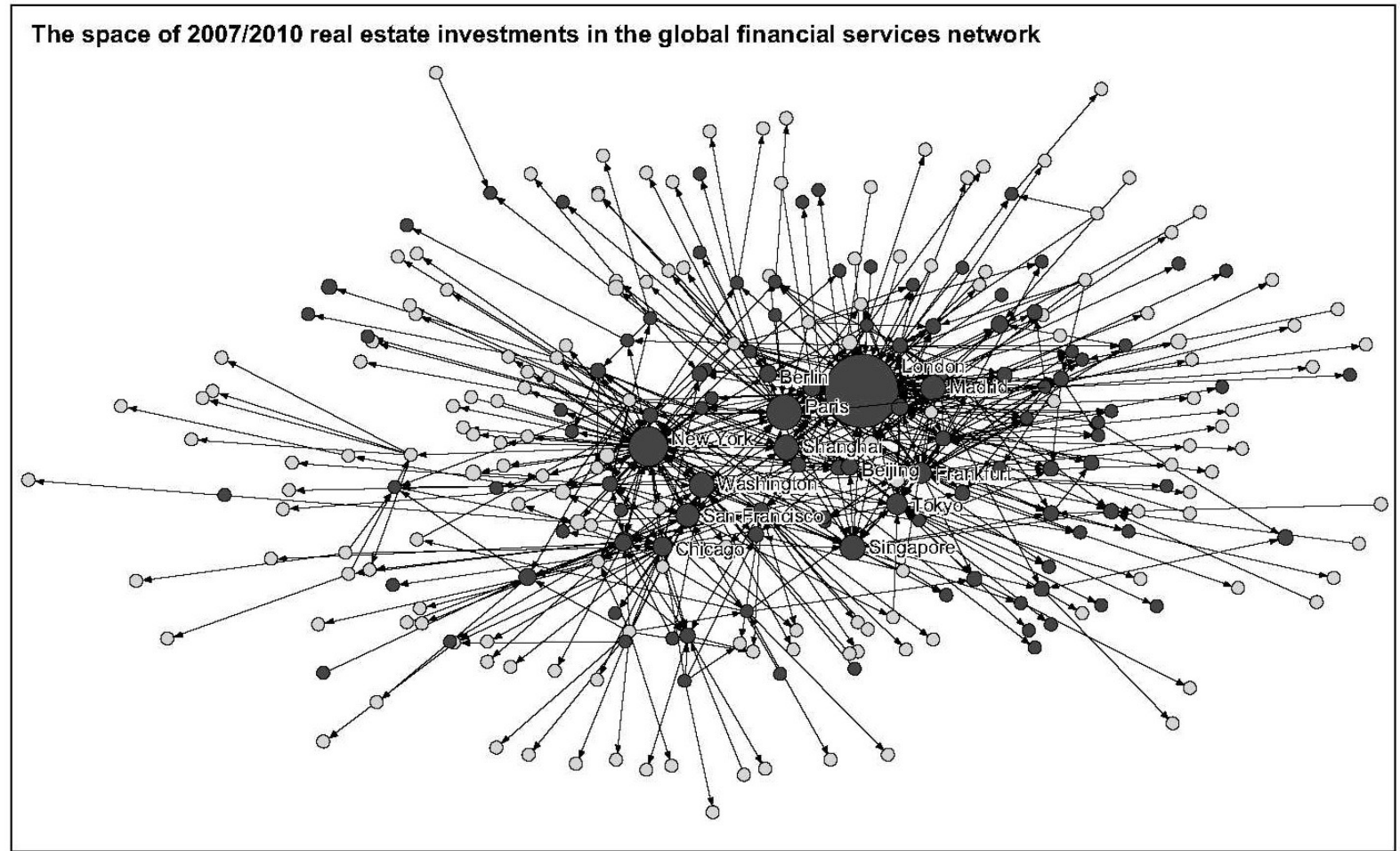

Figure 4 The space of 2007/2010 real estate investments in the global financial services network

Source: Data - Real Capital Analytics: http://www.rcanalytics.com/

The outcome of the Spearman's test shows that the correlation between the two connectivity rankings is 0.646 , and the Pearson test confirms this with a value of 0.611 . The difference between the two test results relates to the fact that the Spearman correlation only considers the order/position of city rank, while the Pearson test focuses on the value of each observation. The QAP test uses random permutations to compare the similarity of networks (Krackhardt, 1988) revealing the extent to which networks are similar through correlation, or whether one network structure can be explained by other network structures through regression. The outcomes demonstrate that financial services and real estate networks are correlated by almost 36 per cent. These results confirm the significance of the interrelationship between the geographies of real estate investment capital flows and global city financial services network connectivity. Direct causal relationships cannot be proved due to the limited availability of real estate time series data. However, international office investments are clearly strongly concentrated in major global cities during the period surveyed. To some extent this is a function of the scale and value of the office space available in those markets - but the availability of that space helps to preserve the role of the major financial cities in global capital networks and the value of the space reflects the economic effect of their network centrality. 
Given the interdependence demonstrated between global city financial services network connectivity and real estate investment flows, it is clearly important to consider the extent to which the concentration of capital flows in global financial services networks and real estate markets represents a risk of contagion for the world's major global cities in financial crises.

The volume of investment flows and the average price per transaction in 2008 (the year when the crisis went viral across cities and countries) was nearly double that in 2007 (Figure 5). It is not possible to show the distribution of flows and average transaction prices across 2008 when the market impacts of the crisis unfolded. However, whilst the number of cities in the world involved in these flows during the four-year period examined has fallen progressively from 189 cities in 2007 to 108 cities in 2010, the largest fall occurred between 2007 and 2008 (from 189 to 138 cities). Thus 2008, when the crisis hit, stood out as an exceptional year. The largest investment flows were focused on a far smaller number of the world's cities. After a large fall in average transaction prices between 2008 (0.33 \$billion) and 2009 (0.20 \$billion), there was just a modest rise between 2009 and 2010 (0.22 \$billion).

Sales activity and the global financial crisis

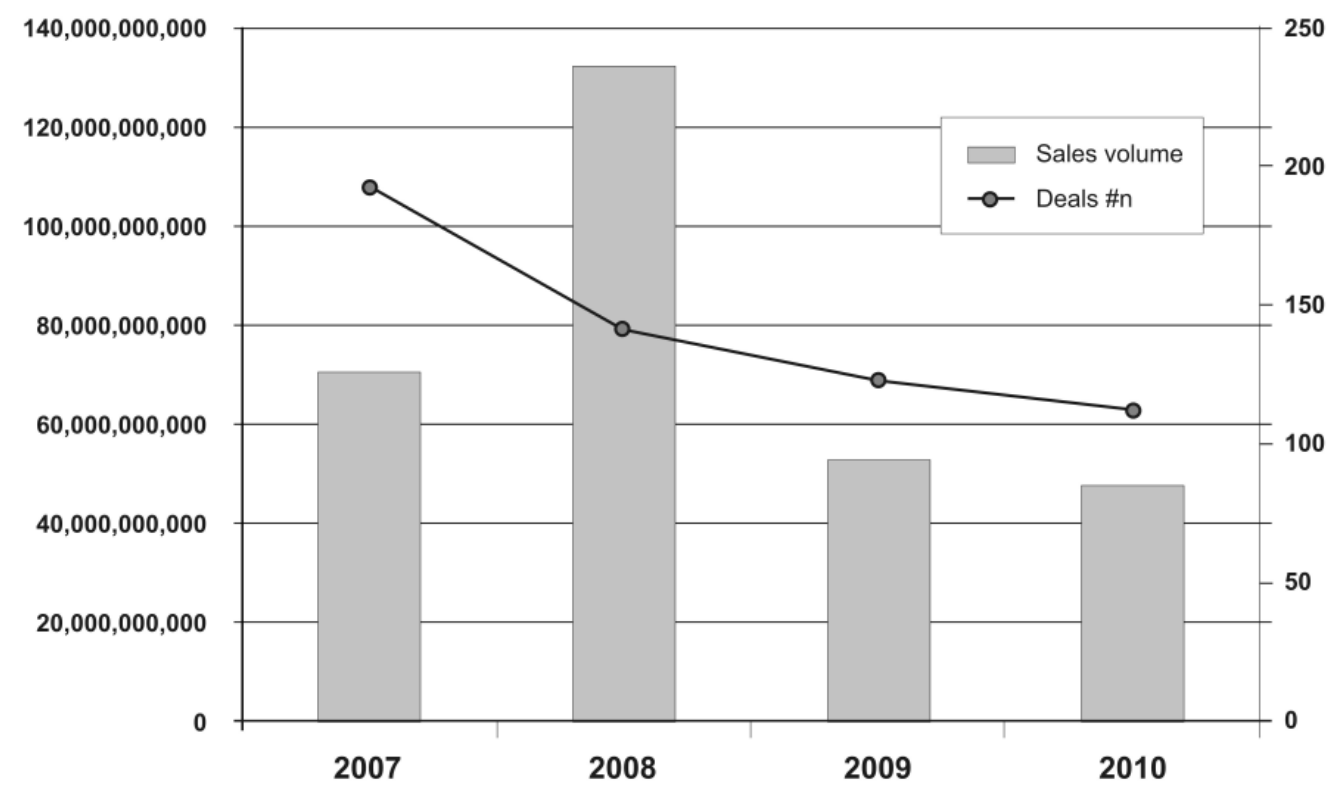

Figure 5 Sales activity and the global financial crisis

Source: Data - Real Capital Analytics: http://www.rcanalytics.com/ 
But while overall inter-city real estate investment links diminished after 2008, they also thickened. So even though overall global investment reduced, flows became focused on the office markets of mature global cities, London and New York. Furthermore, there was also a geographic shift in investment in-flows focusing on a London/New York/Shanghai three node 'triad' (Figure 6). It would seem that the credit crunch 'locked' flows both to these 'old' and 'new' world cities because investors had 'confidence' in their office markets in the context of global financial uncertainty and risk. ${ }^{16}$ The concentration of investment in this triad between 2007 and 2010 suggests that the triad could well represent the new geography of fund and wealth management activity, coordinating global APS networks and real estate capital flows in the future. Interestingly, given its geo-political proximity to mainland China and its established strong world city network position, it would seem that Hong Kong has not played a dominant role in this process of change.

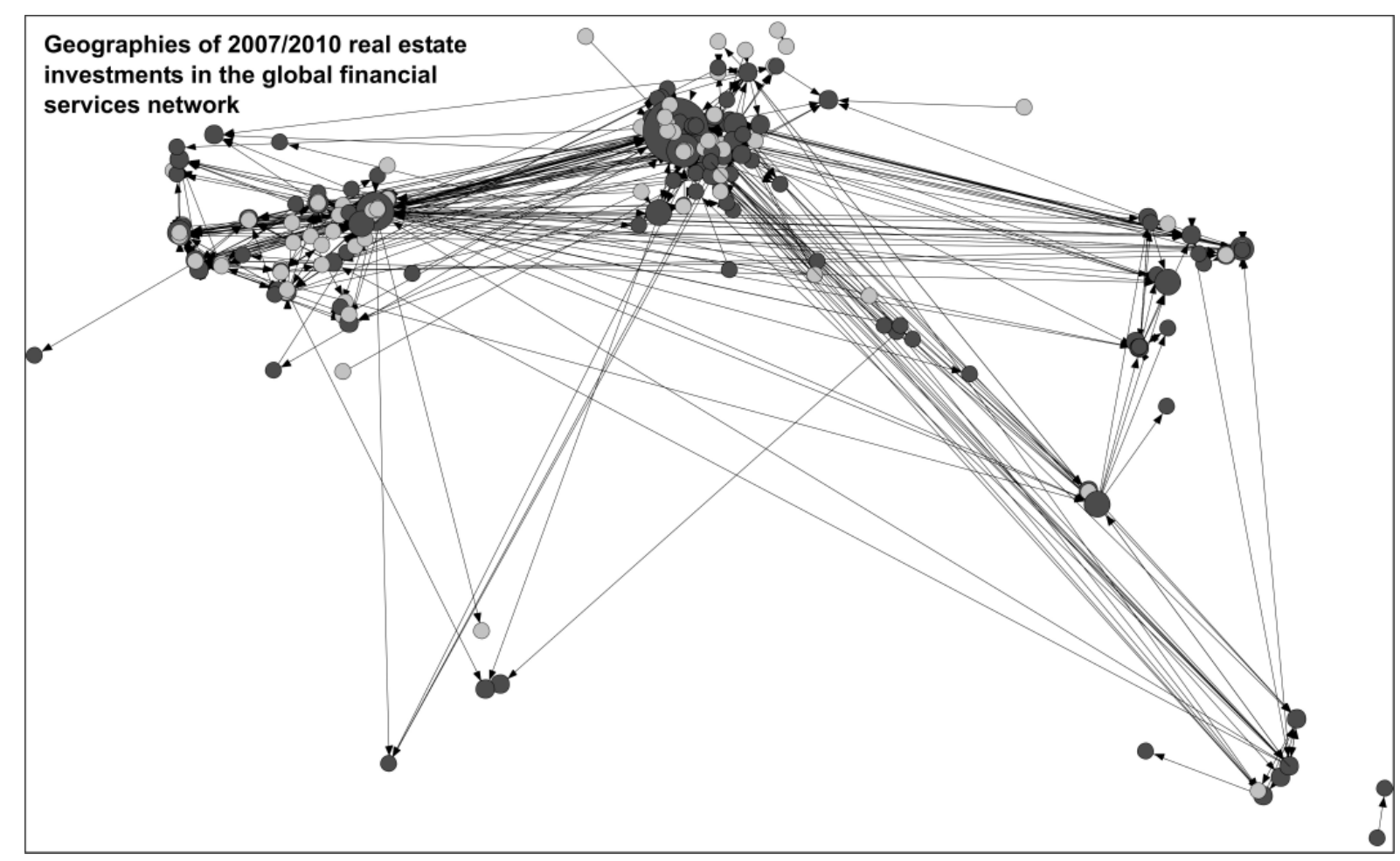

Figure 6 Geographies of 2007/2010 real estate investments in the global financial services network

Source: Data - GaWC (http://www.lboro.ac.uk/gawc/) and Real Capital Analytics: http://www.rcanalytics.com/

Significantly then, in the aftermath of the crisis, the position of the EU in global real estate flows looks strong in comparison with that of the US, reflecting its higher representation of

${ }^{16}$ Not least in that these cities were believed to provide liquidity even in property crises. 
international financial centres. Whereas US cities suffered more severely from the impacts of the crisis, cities in the European Union and London in particular proved to be more attractive locations for real estate investment by the year 2010. Hence, the surprising feature of the crisis has been that the sustainability of international financial clusters, both globally and within Europe, appears to have increased rather than decreased in spite of their exposure to global capital market volatility and the sharp capital value falls generally experienced.

\section{Conclusions: implications for European policy}

In conclusion, we find that two interconnected globalization processes are relevant for policy to promote the position of the EU territory in the advanced global economy (EC, 2011). First, a process of deepening APS concentration prior to the global financial crisis, has led many globalizing cities across the world and in Europe to gain increased connectivity, linking city regions and national economies to the global space of flows. London has developed an especially important role in linking Europe to North America through New York ('the New York-London axis', see also Wójcik, 2013) and, more recently, to the emerging Pacific Asia region through Hong Kong, Shanghai and Beijing. Understanding which specific sectors are making the links between cities is clearly an important consideration in policies both to promote Europe's economic growth in a global context and more balanced development across the EU. Second, increasing interdependencies between financial services networks, office real estate transactions and capital flows, have led to financial functional integration in major global city markets such as that of London. Real estate capital flows can thus be confirmed as being a proxy for city integration in global financial networks, demonstrating the significance of world city network position for capital flows into urban infrastructure which contributes to economic resilience.

It has been hypothesized that a strong interrelationship between capital flows in office markets and depth of a city's financial integration might make global cities like London especially vulnerable to global investment swings associated with financial crisis. However, we have found that in practice there has been an international 'flight to liquidity' by investors, which has favoured the largest real estate markets with higher unit prices and greater transaction volumes. The correlation between financial services network connectivity scores and aggregated volumes of real estate capital flows, suggests that capital has actually flowed to higher-value city locations in the recent financial crisis. We speculate that global financial firms and linked APS, generate agglomeration economies and higher profits from clustering in global cities so that higher rents per square metre paid are capitalized in 
transaction prices which are reflected in real estate investment levels (see Lizieri and Pain, 2013).

These results have an important bearing on the tension between European strategic spatial and economic growth priorities introduced in Chapter 1. Our results indicate that spatial policy objectives for urban polycentricity to rebalance territorial development at metropolitan to EU-wide scales (European Commission, 1999; CEC, 2011, 2012) are in conflict with the operational requirements of global APS networks, that is, functional concentration and clustering in global/globalizing cities. The case of international office real estate investment demonstrates that reduced capital flows during the global financial crisis have become more focused on London but that other European cities have also fared relatively well in a global context. Our analyses show that European cities are interlinked in the global space of flows through complementary relations which have assisted the emergence of globalizing Eastern European cities. Viewing the position of Europe in the global economy from a territorial perspective, its position in the world city network looks strong as illustrated in Figure 7.

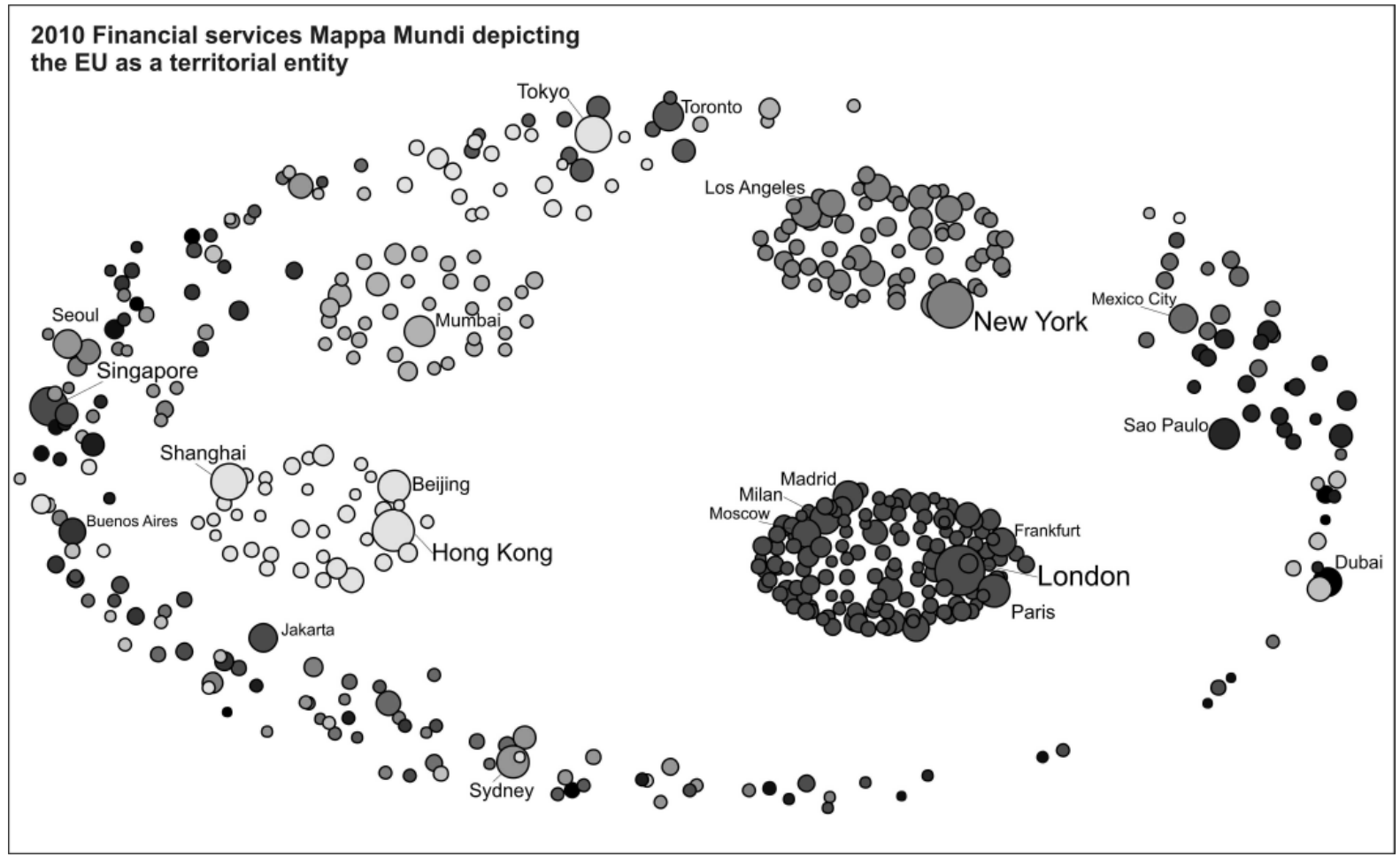

Figure 72010 Financial services mappa mundi depicting the EU as a territorial entity Source: Data - GaWC (http://www.lboro.ac.uk/gawc/) 


\section{Acknowledgements}

The authors are indebted to the Globalization and World Cities (GaWC) Research Network (http://www.lboro.ac.uk/gawc) and Real Capital Analytics Inc. (http://www.rcanalytics.com) for supplying the data that have made the analyses in this chapter possible.

\section{References}

Beaverstock, J. V., Smith, R. G., Taylor, P. J. (2000) World city-network: a new metageography? Annals of the Association of American Geographers 90, 123-134.

Borgatti, S. P., Everett, M. G., Freeman, L. C. (2002) Ucinet 6 for Windows: Software for Social Network Analysis. Analytic Technologies, Lexington, KY.

Brenner, N., Theodore, N. (2002) Cities and the geography of 'actually existing neoliberalism, in Brenner, N. and Theodore, N., (eds.) Spaces of Neoliberalism: Urban Restructuring in North America and Europe, Wiley, Oxford, pp. 349-379.

Castells, M. (1996) The Rise of the Network Society, Blackwell, Oxford.

CEC (2010) Europe 2020: A Strategy for Smart, Sustainable and Inclusive Growth, Commission of the European Communities, Brussels.

CEC (2011) Territorial Agenda of the European Union 2020 - Towards an Inclusive, Smart and Sustainable Europe of Diverse Regions, Commission of the European Communities, Brussels. http://www.eu2011.hu/files/bveu/documents/TA2020.pdf

CEC (2012) Cohesion Policy 2014-2020, Investing in Growth and Jobs, Commission of the European Communities, Brussels.

Coakley, J. (1994) The integration of property and financial markets, Environment \& Planning A, 26, 697-713.

Derudder, B., Taylor, P. J., Ni, P., Vos, A. de, Hoyler, M., Hanssens, H., Bassens, D., Huang, J., Witlox, F., Shen, W., Yang, X. (2010) Pathways of change: shifting connectivities in the world city network, 2000-08, Urban Studies 47, 1861-1877.

Derudder, B., Taylor, P. J., Hoyler, M., Ni, P., Liu, X., Zhao, M., Shen, W., Witlox, F. (2013) Measurement and interpretation of connectivity of Chinese cities in the world city network, 2010, Chinese Geographical Science 23, 261-273.

EC (2000) Presidency Conclusions, Lisbon European Council, 23 and 24 March 2000, http:/www.europarl.europa.eu/summits/lis1_en.htm

European Commission (1999) ESDP: European Spatial Development Perspective: towards balanced and sustainable development of the territory of the European Union. European Commission, Brussels. 
Friedmann, J. (1986) The world city hypothesis, Development and Change 17, 69-83.

Hall, P., Pain, K. (eds) (2006) The Polycentric Metropolis: Learning from Mega-City Regions in Europe. Earthscan, London.

Hanssens, H., Derudder, B., Taylor, P.J., Hoyler, M., Ni, P., Huang, J., Yang, X., Witlox, F. (2011) The changing geography of globalized service provision, 2000-2008, The Service Industries Journal 31, 2293-2307.

Hoyler, M., Kloosterman, R. C., Sokol, M. (2008) Polycentric puzzles - emerging mega-city regions seen through the lens of advance producer services, Regional Studies, 42, 1055-1064.

Hoyler, M., Pain, K. (2002) London and Frankfurt as world cities: changing local-global relations, in Mayr, A., Meurer, M., Vogt, J. (eds), Stadt und Region: Dynamik von Lebenswelten, Deutsche Gesellschaft für Geographie, Leipzig, pp 76-87.

Knox, P., Pain, K. (2010) International homogeneity in architecture and urban development? Special issue on International Real Estate Markets, Global Real Estate Industry, Informationen zur Raumentwicklung, 34, 417-428.

Krackhardt, D. (1988) Predicting with networks: A multiple regression approach to analyzing dyadic data, Social Networks 10, 359-381.

Lizieri, C. (2009) Towers of Capital: Office Markets and International Financial Services, Wiley \& Sons, London.

Lizieri, C., Kutsch, N. (2006) Who Owns the City 2006: Office Ownership in the City of London, University of Reading and Development Securities, Reading.

Lizieri, C., Pain, K. (2013) International office development in global cities: The production of financial space and systemic risk, Regional Studies, doi:10.1080/00343404.2012.753434.

Lizieri, C., Pain, K., Vinciguerra, S. (2012) Real Estate Investment Flows, Working Paper 9, Draft Final Report ESPON 2013 TIGER, http://www.espon.eu/main/Menu_Projects/Menu_AppliedResearch/tiger.html.

Lizieri, C., Reinert, J., Baum, A. (2011) Who Owns the City 2011. Change and Global Ownership of City of London Offices, University of Cambridge and Development Securities, London.

Pain, K. (2011) 'New worlds' for 'old'? Twenty-first-century gateways and corridors: reflections on a European spatial perspective', International Journal of Urban Regional Research 35, 1154-1174.

Pain, K., Vinciguerra, S., Hoyler, M., Taylor, P. J. (2012) Europe in the world city network, Working Paper 3, Draft Final Report ESPON 2013 TIGER, http://www.espon.eu/main/Menu_Projects/Menu_AppliedResearch/tiger.html. 
Peck, J., Tickell, A. (2002) Neoliberalizing space. In Brenner, N., Theodore, N., (eds.) Spaces of Neoliberalism. Urban Restructuring in North America and Western Europe, Wiley, Oxford, pp. 33-57.

Sassen, S. (1991) The Global City: New York, London, Tokyo, Princeton University Press, Princeton.

Sassen, S. (1994) Cities in a World Economy, Pine Forge Press, London.

Sassen, S. (ed.) (2002) Global Networks, Linked Cities, New York/London, Routledge.

Swyngedouw, E., Moulaert, F., Rodriguez, A. (2002) Neoliberal urbanization in Europe: Large-scale urban development projects and the new urban policy, Antipode, 34, 542-577.

Taylor, P. J. (2001) Specification of the world city network, Geographical Analysis, 33, 181194.

Taylor, P. J. (2004) World City Network: A Global Urban Analysis, Routledge, London.

Taylor, P. J. (2012) The interlocking network model. In Derudder, B., Hoyler, M., Taylor, P. J., Witlox, F. (eds), International Handbook of Globalization and World Cities, Edward Elgar, Cheltenham, pp. 51-63.

Taylor, P. J., Aranya, R. (2008) A global 'urban roller coaster'? Connectivity changes in the world city network, 2000-2004, Regional Studies, 42, 1-16.

Taylor, P. J., Beaverstock, J. V., Cook, G., Pandit, N., Pain, K. (2003) Financial Services Clustering and its Significance for London, Corporation of London, London.

Taylor, P. J., Hoyler, M., Pain, K., Vinciguerra, S. (2013) Extensive and intensive globalizations: explicating the low connectivity puzzle of US cities using a city-dyad analysis, Journal of Urban Affairs, doi: 10.1111/juaf.12077

Taylor, P. J., Ni, P., Derudder, B., Hoyler, M., Huang, J., Witlox, F. (eds) (2011) Global Urban Analysis: A Survey of Cities in Globalization, Earthscan, London.

Vinciguerra, S., Taylor, P. J., Hoyler, M., Pain, K. (2010) Contemporary Mappa Mundi: American exceptionalism in the world city network, Environment and Planning A, 42, 1271-1272.

Wójcik, D. (2013) The dark side of NY-LON: financial centres and the global financial crisis, Urban Studies, 50, 2736-2752. 